\title{
Evaluation of spontaneous retinal venous pulsation in primary open- angle and primary angle-closure glaucoma patients
}

Sylves Patrick ${ }^{1,2}$, Chan Hui Tze ${ }^{1}$, Rasdi Abdul Rashid ${ }^{1}$, Liza Sharmini Ahmad Tajudin ${ }^{1}$

${ }^{1}$ Department of Ophthalmology, School of Medical Sciences, Universiti Sains Malaysia Health Campus, Kota Bharu, Kelantan, Malaysia; ${ }^{2}$ Faculty of Medicine and Health Sciences, Universiti Malaysia Sabah, Jalan, Kota Kinabalu, Sabah, Malaysia

\section{Abstract}

Introduction: Spontaneous retinal venous pulsation (SRVP) is a rhythmic variation in the calibre of one or more retinal veins. The incidence of SRVP was reduced in glaucoma patients. It was also reduced in people with raised intracranial pressure compared to a healthy population.

Purpose: The main objective was to report the frequency and rate of SRVP in primary open-angle glaucoma (POAG) and primary angle-closure glaucoma (PACG) patients and to associate these with the severity of glaucoma in Malay patients.

Design of study: A comparative cross-sectional study.

Materials and methods: A comparative cross-sectional study involving primary glaucoma patients attending the eye clinic at Hospital Universiti Sains Malaysia (HUSM), Kelantan, Malaysia, was performed between December 2015 and June 2017. The main outcomes measured were the presence and rate of SRVP using a confocal scanning laser ophthalmoscope (Spectralis High-Resolution Optical Coherence Tomography Angiography, Heidelberg Engineering GmbH, Heidelberg, Germany). In the presence of SRVP, the rate of SRVP in one minute was counted manually based on the real-time fundus movie recorded using the confocal scanning laser ophthalmoscope.

Correspondence: Dr. Liza Sharmini Ahmad Tajudin, Professor of Ophthalmology and Senior Consultant Ophthalmologist (Glaucoma), Department of Ophthalmology, School of Medical Sciences, Universiti Sains Malaysia, Health Campus, 16150 Kota Bharu, Kelantan, Malaysia.

E-mail: liza@usm.my 
Results: Thirty-eight POAG, 14 PACG, and 51 control group subjects were included. There was a significantly lower incidence of SRVP in primary glaucoma patients than in the control group $(p=0.003)$. The presence of SRVP was significantly lower in POAG than PACG $(p=0.04)$. There was no significant difference in the rate of SRVP between primary glaucoma patients and the control group ( $p=0.873)$ or between the POAG group and PACG group $(p=0.511)$. There was no association of incidence $(p=0.574)$ and rate $(p=0.167)$ of SRVP according to the severity of glaucoma. Systolic blood pressure $(95 \% \mathrm{Cl}: 0.95-1.00, p=0.038)$ and retinal nerve fibre layer thickness ( $95 \% \mathrm{Cl}: 1.01-1.09, p=0.008$ ) showed a significant association with the presence of SRVP.

Conclusions: SRVP is a potential predictive factor for detection of primary glaucoma. The role of SRVP in the severity of glaucoma is still unclear. The role of SRVP in PACG patients warrants further studies in the future.

Keywords: primary angle-closure glaucoma, primary open-angle glaucoma, retinal venous pulsation, spontaneous retinal venous pulsation

\section{Penilaian denyutan spontan salur darah vena retina pada pesakit glaukoma bersudut terbuka primer dan bersudut tertutup primer}

\section{Abstrak}

Pengenalan: Denyutan spontan salur darah vena retina (SRVP) adalah variasi berirama satu atau lebih kaliber salur darah vena retina. Didapati SRVP ini adalah berkurangan dalam pesakit glaukoma. Ia juga berkurangan pada pesakit yang mengalami tekanan intracranial yang tinggi berbanding orang yang sihat.

Tujuan: Untuk melaporkan kekerapan dan kadar SRVP pada pesakit glaukoma bersudut terbuka primer(POAG) dan bersudut tertutup primer (PACG) dan mengaitkannya dengan keterukkam penyakit glaukoma di kalangan pesakit Melayu.

Reka bentuk kajian: Kajian rentas keratan perbandingan.

Bahan dan kaedah: Kajian rentas keratan perbandingan yang melibatkan pesakit glaukoma primer yang menghadiri klinik mata di Hospital Universiti Sains Malaysia (HUSM), Kelantan, Malaysia telah dilaksanakan antara Disember 2015 dan Jun 2017. Hasil utama yang diukur adalah kehadiran dan kadar SRVP menggunakan ophthalmoscope laser pengimbasan confocal (Spectralis High-Resolution Optical Coherence Tomography Angiography, Heidelberg Engineering $\mathrm{GmbH}$, Heidelberg, Jerman). Sekiranya terdapat kehadiran SRVP, 
kadar SRVP dalam satu minit dikira secara manual berdasarkan filem fundus masa nyata yang direkodkan menggunakan ophthalmoscope laser pengimbasan confocal.

Keputusan: Seramai 38 POAG, 14 PACG, dan 51 mata dari subjek dalam kumpulan kawalan di rekrutkan dalam kajian ini. Kekerapan SRVP adalah rendah secara signifikan dalam pesakit glaukoma primer berbanding kumpulan kawalan $(\mathrm{p}=0.003)$. Kekerapan SRVP jauh lebih rendah dalam pesakit POAG daripada PACG $(\mathrm{p}=0.04)$. Tetapi tiada perbezaan yang signifikan dalam kadar kekerapan SRVP di antara pesakit glaukoma primer dan kumpulan kawalan $(\mathrm{p}=0.873)$ atau antara kumpulan POAG dan kumpulan PACG $(\mathrm{p}=0.511)$. Tiada perkaitan didapati antara kekerapan $(\mathrm{p}=0.574)$ dan kadar $(\mathrm{p}=0.167)$ SRVP mengikut keterukkan penyakit glaukoma. Tekanan darah sistolik (95\% CI: 0.95-1.00, p $=0.038)$ dan ketebalan lapisan serat saraf retina (95\% CI: 1.01-1.09, $\mathrm{p}=0.008$ ) menunjukkan perkaitan yang signifikan dengan kekekerapan SRVP.

Kesimpulan: SRVP mempunyai potensi sebagai faktor ramalan untuk pengesanan glaukoma primer. Peranan SRVP dalam keterukan glaukoma masih tidak jelas. Peranan SRVP dalam pesakit PACG memerlukan kajian lanjut pada masa akan datang.

Kata kunci: denyutan vena retina, denyutan vena retina spontan, glaukoma sudut terbuka primer, glaukoma sudut tertutup primer

\section{Introduction}

The concept of spontaneous retinal venous pulsation (SRVP) was first described by Coccius in 1853 after the invention of the direct ophthalmoscope. ${ }^{1}$ SRVP is a rhythmic variation in the calibre of one or more retinal veins. ${ }^{2}$ SRVP is commonly seen on the retina or optic disc surface near to where the veins exit the eye. ${ }^{3}$ There is no established pathogenesis of SRVP, and it is thought to be complex. The most acceptable explanation is due to changes in the retinal venous pressure along the vein between two compartments: intraocular pressure (IOP) and retrobulbar compartments. The IOP compartment is the space within the eyeball containing the peripheral retinal veins up to and including the prelaminar portion of the central retinal vein. The retrobulbar compartment is the space outside the eyeball containing the retrolaminar and intraneural portions of the central retinal vein. The pressure change arises when the retinal vein exits the eye through the lamina cribrosa towards the retrobulbar region. Changes in IOP are believed to affect the IOP compartment. External pressure, mainly from the cerebrospinal (CSF) pressure and tissue pressure surrounding the optic nerve, affects the retrobulbar compartment. ${ }^{2,3}$ The imbalance between these two compartments may affect the SRVP. 
In a healthy population, SRVP has been reported to occur between $74.4 \%$ and $98 \% .^{4-10}$ However, the incidence of SRVP was reduced in glaucoma patients and patients with raised intracranial pressure..$^{5,6,8-11}$ The reason for the absence of SRVP in glaucoma patients is still not fully understood. The most likely explanation, thus far, is due to an increase in central retinal vein (CRV) resistance. ${ }^{8}$ An increase in CRV resistance is due to intrinsic and extrinsic alterations. As glaucoma is a disease of ageing, systemic comorbidities such as systemic hypertension are not uncommon. ${ }^{12-20}$ The changes in the endothelium and vessel wall that are intrinsic to the ageing process or the consequence of hemodynamic stress are also believed to be responsible for CRV resistance in glaucoma patients. ${ }^{21}$ On the other hand, extrinsic compressive connective tissue remodelling response in the lamina cribrosa may also play a role for the absence of SRVP in glaucoma patients. ${ }^{22}$ Absence of SRVP was also found in patients with increased intracranial pressure (ICP). ${ }^{6,11}$ On the contrary, glaucoma patients are believed to have low ICP. ${ }^{23-25}$ Indeed, not all glaucoma patients showed absence of SRVP.

On the other hand, there is evidence suggesting a potential role of SRVP in the severity of primary open-angle glaucoma (POAG). This is based on the finding of higher frequency of SRVP in early glaucoma compared to moderate and advanced glaucoma among POAG patients who achieved target pressure. ${ }^{9}$ The frequency of SRVP also differs according to the types of glaucoma: lower frequency of SRVP in POAG compared to normotensive glaucoma (NTG). ${ }^{5}$ To the best of our knowledge, there is no data reported on SRVP in primary angle-closure glaucoma (PACG). The main objective of this study was to report the frequency and rate of SRVP in POAG and PACG patients, and to associate these with the severity of glaucoma in Malay patients.

\section{Materials and methods}

This was a comparative cross-sectional study involving primary glaucoma patients: POAG and PACG. Purposive sampling was conducted on primary glaucoma patients attending the eye clinic, Hospital Universiti Sains Malaysia (HUSM), Kelantan, Malaysia, between December 2015 and June 2017. Control subjects were recruited from hospital staff and HUSM students. This study received ethical approval from the Ethics Committee Board of Universiti Sains Malaysia and was conducted in accordance with the Declaration of Helsinki. Written informed consent was obtained from all the subjects prior to their participation in this research.

\section{Patient recruitment}

The inclusion criteria were Malay subjects. "Malay" was defined as a person who ascribed to the religion of Islam, habitually spoke the Malay language, conformed to Malay customs, and whose ancestors were Malay. ${ }^{26}$ Those with confirmed cases 
of POAG and PACG who were able to produce two consecutive reliable and reproducible visual field tests were included. POAG was defined as a glaucomatous optic neuropathy associated with visual field loss in the absence of other ocular diseases or congenital anomalies, with no evidence of angle closure. ${ }^{27}$ PACG was defined as a glaucomatous optic neuropathy with the presence of iridotrabecular contact (ITC) associated with visual field loss in the absence of other ocular diseases or congenital anomalies. ${ }^{27}$ The reliability of the Humphrey visual field (HVF) test was defined as a fixation loss of less than 20\%, a false positive response of less than $33 \%$, and a false negative response of less than $33 \% .{ }^{28}$ Control subjects who were healthy subjects also underwent an HVF test. Only those who were able to produce two consecutive reliable and reproducible visual field tests were included.

The exclusion criteria were subjects under 18 years old, with a history of ocular trauma and uveitis, and a history of previous intraocular surgery other than uncomplicated cataract surgery. Those with ocular and systemic diseases affecting the visual fields - diabetic retinopathy, retinal vein occlusion, ischemic optic neuropathy and stroke - were excluded. In addition, poor quality image of CRV and inadequate real-time fundus movies were also excluded.

All the eligible subjects underwent visual acuity testing using the Snellen visual acuity chart for distance (Ametek Reichert Technologies, NY, USA), anterior segment and dilated fundus examinations using a slit lamp biomicroscope (HaagStreit UK, England). Gonioscopic examination and IOP measurement using the Goldmann applanation tonometer were also conducted. Optic nerve head (ONH) parameters and retinal nerve fibre layer (RNFL) thickness were evaluated using optical coherence tomography (OCT) (Carl Zeiss Meditec Inc., Dublin, CA, USA). Visual field analysis was conducted using the Swedish interactive threshold algorithm (SITA) standard of 24-2 by Humphrey automated perimetry (Carl Zeiss Meditec Inc., Dublin, CA, USA). Blood pressure (BP) was also measured using a sphygmomanometer and pulse rate (PR) was recorded.

\section{SRVP image acquisition}

The SRVP image was obtained using a confocal scanning laser ophthalmoscope (Spectralis High-Resolution OCT Angiography, Heidelberg Engineering GmbH, Heidelberg, Germany) in near-infrared mode $(820 \mathrm{~nm})$ from a dilated pupil. The real-time fundus movie was recorded for one minute and centred on the $\mathrm{ONH}$. The observation for SRVP on the optic disc was conducted by two independent masked observers (SP and CHT) at two different times. The presence of SRVP was based on an agreement between the two independent observers. If there was a disagreement, a third observer (RAR) was asked to evaluate. In the presence of SRVP, the rate of the SRVP in one minute was counted manually. If both eyes were eligible, only the right eye was selected. The SRVP image acquisitions were made by the same qualified and trained personnel. 


\section{Glaucoma severity score}

Two reliable visual fields were obtained from primary glaucoma patients within three months of the recruitment period. Patients were excluded after three failed attempts in producing two reliable visual fields. Glaucoma severity was scored using a modified Advanced Glaucoma Intervention Study (AGIS) scoring system. ${ }^{29}$ AGIS scoring was conducted by a masked glaucoma consultant (LS).

All relevant data were analysed using Statistical Package for Social Sciences (SPSS) for Windows, Version 22.0 (IBM Corp., Armonk, NY, USA). Double entry of data was practised to avoid wrong or missing entry of information. The categorical variables, including the SRVP frequency, were described using frequency and percentage. The numerical variables were described based on the distribution of the data. Mean and standard deviation were used for normally distributed data, median and interquartile range for skewed data. The comparison between groups was analysed using a Pearson chi-squared test, Fisher exact test, Mann-Whitney $\mathrm{U}$ test, independent t-test, and one-way analysis of variance (ANOVA). Simple and multiple logistic regressions were performed to determine the factors associated with SRVP. The potential factors included in the analysis were age, gender, systolic BP, diastolic BP, PR, IOP, HVF parameters, and ONH parameters. The statistical significance level was set at $p<0.05$.

\section{Results}

A total of 52 primary glaucoma patients were included in this study; 38 had POAG and 14 had PACG. A total of 33 primary glaucoma patients were excluded because of failure to produce reliable visual fields. Patients with primary glaucoma (POAG and PACG) were significantly older. Higher frequency of systemic comorbidities and higher systolic BP were identified among primary glaucoma patients (Table 1). The majority of the primary glaucoma patients were on monotherapy with mean IOP of $15.4 \pm 3.2 \mathrm{mmHg}$ (Table 2). There was a significant difference in the incidence of SRVP between primary glaucoma patients and the control group $(p=0.003)$ (Table 3). The presence of SRVP in POAG was $13(34.2 \%)$ and PACG was $11(78.6 \%)$, with a statistically significant difference $(p=0.04)$.

However, there was no difference in the rate of SRVP between primary glaucoma patients and the control group $(p=0.873)$ (Table 3$)$. The SRVP rates in the POAG group ( $73.9 \pm 10.5$ beats per minute) and PACG group ( $71.2 \pm 8.7$ beats per minute) were almost the same, and was not statistically significant $(p=0.511)$. There were a total of $24(46.2 \%)$ mild, $9(17.3 \%)$ moderate, and 19 (36.5\%) severe glaucoma patients included in the study. There was no significant difference in the incidence of SRVP $(p=0.574)$ and the rate of SRVP $(P=0.167)$ according to severity of primary glaucoma (Table 4). In multiple logistic regression using the backward method, the systolic BP and RNFL thickness were significant factors affecting SRVP. A reduction 
in $1 \mu \mathrm{m}$ of RNFL thickness had $5 \%$ lower odds to have SRVP present $(95 \% \mathrm{Cl}$ : 1.01-1.09, $p=0.008$ ) after being adjusted for age, gender, systolic BP, diastolic BP, PR, IOP, HVF parameters, vertical cup-to-disc ratio (VCDR), and neuro-retinal rim area. An increase in $1 \mathrm{mmHg}$ of systolic BP had $2 \%$ lower odds to have SRVP present (95\% $\mathrm{Cl}$ : 0.95-1.00, $p=0.038$ ) after being adjusted for age, gender, diastolic BP, PR, IOP, HVF parameters, and ONH parameters (Table 5).

Table 1. General demographics and descriptive statistics of primary glaucoma patients and control group

\begin{tabular}{|c|c|c|c|}
\hline \multirow[t]{2}{*}{ Variables } & \multicolumn{2}{|l|}{ Subjects $(n=103)$} & \multirow[t]{2}{*}{ p-value } \\
\hline & $\begin{array}{l}\text { Primary glaucoma } \\
(n=52)\end{array}$ & $\begin{array}{l}\text { Control group ( } \mathrm{n} \\
=51 \text { ) }\end{array}$ & \\
\hline Age (years) & & & $<0.001^{c}$ \\
\hline Median (range) & $70.5(51.0-89.0)$ & $50.0(18.0-78.0)$ & \\
\hline Interquartile range & 9 & 26 & \\
\hline Gender & & & $0.370^{\mathrm{d}}$ \\
\hline Male & $29.0(55.8)$ & $18.0(35.3)$ & \\
\hline Female & $23.0(44.2)$ & $33.0(64.7)$ & \\
\hline \multicolumn{4}{|l|}{ Systemic comorbidities } \\
\hline Hypertension & $30.0(57.7)$ & $7.0(13.7)$ & $<0.001^{\mathrm{d}}$ \\
\hline Diabetes mellitus & $23.0(44.2)$ & $2.0(3.9)$ & $<0.001^{\mathrm{d}}$ \\
\hline Hyperlipidaemia & $16.0(30.8)$ & $2.0(3.9)$ & $<0.001^{\mathrm{d}}$ \\
\hline Ischemic heart disease & $5.0(9.6)$ & $2.0(3.9)$ & $0.437^{e}$ \\
\hline Chronic renal disease & $1.0(1.9)$ & $0.0(0.0)$ & $0.999^{e}$ \\
\hline $\begin{array}{l}\text { Systolic blood pressure } \\
(\mathrm{mmHg})\end{array}$ & & & $<0.001^{c}$ \\
\hline Median (range) & $145.0(105.0-201.0)$ & \begin{tabular}{|l|}
$120.0(99.0-$ \\
$194.0)$ \\
\end{tabular} & \\
\hline Interquartile range & 31 & 16 & \\
\hline Pulse rate (beats/min) & & & $<0.080^{f}$ \\
\hline Mean \pm SD & $72.2 \pm 10.5$ & $75.8 \pm 10.3$ & \\
\hline
\end{tabular}

SD: standard deviation; 'Mann-Whitney U test; ${ }^{\mathrm{d} P e a r s o n}$ chi-squared test; ${ }^{\mathrm{e}} \mathrm{Fisher}$ exact test; findependent t-test.

Data are presented as the frequency (percentage) unless otherwise indicated. 
Table 2. Ocular parameters and descriptive statistics of the primary glaucoma patients

\begin{tabular}{|c|c|}
\hline Variables & Primary glaucoma $(n=52)$ \\
\hline \multicolumn{2}{|l|}{ IOP (mmHg) } \\
\hline Mean \pm SD & $15.4 \pm 3.2$ \\
\hline \multicolumn{2}{|c|}{$\begin{array}{l}\text { IOP according to glaucoma severity based on modified } \\
\text { AGIS scoring system }(\mathrm{mmHg}) \text { : }\end{array}$} \\
\hline \multicolumn{2}{|l|}{ Mild } \\
\hline Mean \pm SD & $14.2 \pm 3.2$ \\
\hline \multicolumn{2}{|l|}{ Moderate } \\
\hline Mean \pm SD & $18.1 \pm 2.5$ \\
\hline \multicolumn{2}{|l|}{ Severe } \\
\hline Mean \pm SD & $15.5 \pm 2.7$ \\
\hline \multicolumn{2}{|c|}{ Humphrey visual field parameters: } \\
\hline \multicolumn{2}{|l|}{ Mean deviation $(\mathrm{dB})$} \\
\hline Median (range) & $-7.9(-32.9-1.6)$ \\
\hline Interquartile range & 17.7 \\
\hline \multicolumn{2}{|l|}{ Visual field index } \\
\hline Median (range) & $82.5(2.0-100.0)$ \\
\hline Interquartile range & 58 \\
\hline \multicolumn{2}{|c|}{ Pattern standard deviation } \\
\hline Median (range) & $6.6(1.3-13.1)$ \\
\hline Interquartile range & 7.6 \\
\hline \multicolumn{2}{|l|}{ Optic nerve parameters: } \\
\hline \multicolumn{2}{|l|}{ Vertical cup-disc ratio } \\
\hline Median (range) & $0.8(0.5-0.9)$ \\
\hline Interquartile range & 0.2 \\
\hline \multicolumn{2}{|c|}{ Average RNFL thickness $(\mu \mathrm{m})$} \\
\hline Mean \pm SD & $70.3 \pm 15.0$ \\
\hline \multicolumn{2}{|c|}{ Neuro-retinal rim area $\left(\mathrm{mm}^{2}\right)$} \\
\hline Mean \pm SD & $0.8 \pm 0.3$ \\
\hline
\end{tabular}




\begin{tabular}{|l|l|}
\hline Variables & Primary glaucoma $(\boldsymbol{n}=\mathbf{5 2})$ \\
\hline Management $[n(\%)]$ & \\
\hline Monotherapy & $17.0(32.7)$ \\
\hline Dual therapy & $14.0(26.9)$ \\
\hline Triple therapy & $12.0(23.1)$ \\
Quadruple therapy & $9.0(17.3)$ \\
\hline
\end{tabular}

IOP: intraocular pressure; AGIS: Advanced Glaucoma Intervention Study: SD: standard deviation: RNFL: retinal nerve fibre layer. Data are presented as the frequency (percentage) unless otherwise indicated.

Table 3. The incidence and rate of SRVP between primary glaucoma patients and controls

\begin{tabular}{|c|l|l|l|}
\hline \multirow{2}{*}{ Variables } & \multicolumn{2}{|l|}{ Subjects $(\boldsymbol{n}=\mathbf{1 0 3})$} & \multirow{2}{*}{-value } \\
\cline { 2 - 4 } & $\begin{array}{l}\text { Primary glaucoma } \\
(\mathbf{n = 5 2})\end{array}$ & $\begin{array}{l}\text { Control group } \\
(\boldsymbol{n}=\mathbf{5 1})\end{array}$ & \\
\hline SRVP & $24.0(46.2)$ & $38.0(74.5)$ & $0.003^{\mathrm{d}}$ \\
\hline Rate of SRVP (beats/min) & & & $0.873^{\mathrm{c}}$ \\
\hline Median (range) & $71.0(59.0-90.0)$ & $72.0(56.0-97.0)$ & \\
\hline Interquartile range & 17 & 14 & \\
\hline
\end{tabular}

SRVP: spontaneous retinal venous pulsation; ${ }^{\mathrm{d}}$ Pearson chi-squared test; 'Mann-Whitney U test. Data are presented as the frequency (percentage) unless otherwise indicated.

Table 4. The incidence and rate of SRVP according to primary glaucoma severity

\begin{tabular}{|l|l|l|l|l|}
\hline \multirow{2}{*}{ Variables } & \multicolumn{2}{|l|}{ Glaucoma severity } & \multirow{2}{*}{ p-value } \\
\cline { 2 - 4 } & $\begin{array}{l}\text { Mild } \\
(\mathbf{n}=\mathbf{2 4})\end{array}$ & $\begin{array}{l}\text { Moderate } \\
(\mathbf{n}=\mathbf{9})\end{array}$ & $\begin{array}{l}\text { Severe } \\
(\mathbf{n}=\mathbf{1 9})\end{array}$ & \\
\hline SRVP & $13.0(54.2)$ & $4.0(16.7)$ & $7.0(29.2)$ & $0.574^{\mathrm{e}}$ \\
\hline Rate of SRVP (beats/min) & & & & $0.167^{\mathrm{g}}$ \\
\hline Mean \pm SD & $75.9 \pm 10.6$ & $66.8 \pm 6.9$ & $69.9 \pm 7.1$ & \\
\hline
\end{tabular}

SD: standard deviation; SRVP: spontaneous retinal venous pulsation; ${ }^{e}$ Fisher exact test; 'One-way analysis of variance (ANOVA). Data are presented as the frequency (percentage) unless otherwise indicated. 
Table 5. Multiple logistic regression on factor affecting SRVP.

\begin{tabular}{|c|c|c|c|c|c|c|}
\hline \multirow[b]{2}{*}{ Variables } & \multicolumn{3}{|c|}{ Simple logistic regression } & \multicolumn{3}{|c|}{ Multiple logistic regression } \\
\hline & $\mathbf{B}^{\mathbf{a}}$ & $\begin{array}{l}\text { Crude OR (95\% } \\
\mathrm{CI})\end{array}$ & p-value & $\mathbf{B}^{\mathbf{b}}$ & $\begin{array}{l}\text { Adjusted OR } \\
(95 \% \mathrm{CI})\end{array}$ & p-value \\
\hline Age (years) & -0.02 & $0.98(0.96,1.01)$ & 0.136 & 0.46 & $1.05(1.00,1.09)$ & 0.310 \\
\hline $\begin{array}{l}\text { Systolic blood } \\
\text { pressure } \\
\text { (mmHg) }\end{array}$ & -0.02 & $0.98(0.96,1.00)$ & 0.017 & -0.03 & $0.98(0.95,1.00)$ & 0.038 \\
\hline \multicolumn{7}{|c|}{ Optic nerve parameters: } \\
\hline $\begin{array}{c}\text { Vertical } \\
\text { cup-disc ratio }\end{array}$ & -4.78 & $0.01(0.00,0.14)$ & 0.001 & -3.19 & $0.04(0.00,1.09)$ & 0.056 \\
\hline \begin{tabular}{l}
\multicolumn{1}{c}{ Average } \\
RNFL \\
thickness \\
$(\mu \mathrm{m})$
\end{tabular} & 0.04 & $\begin{array}{l}7.90(2.45 \\
25.47)\end{array}$ & $<0.001$ & 0.05 & $1.05(1.01,1.09)$ & 0.008 \\
\hline
\end{tabular}

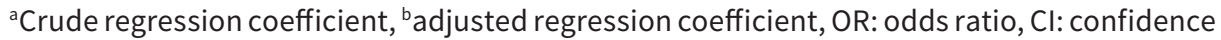
interval, B: regression coefficient, RNFL: retinal nerve fibre layer. Backward multiple logistic regression method was applied. There was no multicollinearity detected and no interaction amongst independent variables. Hosmer Lemeshow test, $\mathrm{p}$-value $=0.947$. Classification table $69.9 \%$ correctly classified. The area under the receiver operating characteristics (ROC) curve was $72.2 \%$.

\section{Discussion}

There was a significant reduction in the incidence of SRVP in primary glaucoma patients in this study. The findings from the current study are almost similar to several findings in Caucasians. However, in population-based studies, Asians were reported to have a significantly wider mean retinal arteriolar and venular calibres compared to Caucasians. ${ }^{30,31}$ There is minimal knowledge on SRVP among Asians. Seo et al. reported a significantly lower incidence of SRVP in POAG patients (53.3\%) compared to glaucoma suspects (86.3\%) among the Korean population..$^{32}$ In their study, glaucoma suspects were used as a comparison. Glaucoma suspects may sometimes be considered early-stage POAG and this may affect the accuracy of the study. ${ }^{33,34}$ In addition, SRVP evaluation in previous studies was performed using a slit-lamp examination with a $60 \mathrm{D}$ or $78 \mathrm{D}$ ophthalmoscopic lens, fundus camera, and confocal scanning laser ophthalmoscope (Spectralis HRA) in near-infrared mode $(820 \mathrm{~nm})$ installed with an "eye movement correction tool". 5,8,10,32,35,36

Most studies reported SRVP in POAG and NTG patients but none in PACG. 5,9,10,32,36 Since PACG is responsible for more blindness than POAG, the detection of SRVP may be important in the screening and management of PACG. ${ }^{37}$ However, the number 
of PACG included in the present study was too small. SRVP was observed in 11 of 14 (78.6\%) PACG patients. There is a potential higher incidence of SRVP in PACG compared to POAG that is yet to be proven, although this may not be in agreement with the two-compartment theory. ${ }^{2,3}$

In our study, the SRVP rate in primary glaucoma patients and controls was almost similar. Even between patients with different severity of primary glaucoma, the SRVP rate was almost the same. One study found that SRVP collapses in phases with IOP at systole and expansion occurs during IOP at diastole. ${ }^{38}$ On the contrary, another study found that SRVP collapsed in phase with ocular diastole and expansion occurred during ocular systole. ${ }^{39}$ The cardiac cycle drives IOP oscillation, with peak IOP occuring during systole. ${ }^{38,39}$ The heart rate reflects the number of cardiac cycles per unit of time, while the pulse rate is close or equal to the heart rate in people with normal and healthy hearts. Based on this knowledge, we have assumed that the SRVP rate measurement could be done by measuring the heart rate or the pulse rate.

Based on the two-compartment theory, SRVP is related to IOP and ICP. Glaucoma severity is closely related to IOP. ${ }^{33,40,41}$ High IOP may lead to an acceleration of optic neuropathy. ${ }^{41}$ Thus, absence of SRVP may be related to glaucoma severity. A lower incidence of SRVP was observed in severe glaucoma cases. ${ }^{9,32}$ Higher incidence of SRVP was observed in mild glaucoma patients compared to severe glaucoma. ${ }^{32}$ Seo et al. found that the incidence of SRVP reduces as severity increases, with mild cases having an SRVP incidence of $63.4 \%$, moderate cases an incidence of $42.1 \%$, and severe cases an incidence of $26.7 \%$. $^{32}$ However, in the present study there was no significant association between glaucoma severity and incidence of SRVP. In fact, we found a lower incidence of SRVP in moderate glaucoma. This is mainly due to the small number of patients causing an unequal distribution of patients according to severity. In the future, it would be best to base recruitment on glaucoma severity.

There is evidence supporting the postulation that better IOP control reduces the incidence of SRVP at any stage of the disease. ${ }^{32,36}$ Since the mean IOP was $15.4 \pm$ $3.2 \mathrm{mmHg}$, this may partially explain the negative association between SRVP and severity of primary glaucoma. However, target IOP was not considered in our study. Our study used mean IOP, which is not ideal compared to appropriate target IOP. Target IOP differs according to severity of glaucoma ${ }^{42}$ and is dynamic, especially when there is evidence of progression. ${ }^{27,43}$ On the contrary, there was a higher frequency of SRVP in control subjects with lower mean IOP $(14.6 \pm 2.4 \mathrm{mmHg})$.

Ideally, the comparison should be made at the initial presentation before initiation of treatment and prospective follow-up. As the present study was a cross-sectional study, stopping IOP-lowering drugs was not only unethical but may have also increased the risk of progression. IOP-lowering drugs, such as topical beta blockers, may reduce the incidence of SRVP at any glaucoma stage, as has been reported in a few studies. ${ }^{32,36}$ Moreover, systemic comorbidities such 
as hypertension and diabetes mellitus are not uncommon in glaucoma patients. There was a higher number of hypertensive patients among primary glaucoma patients and systemic hypertensive drugs were not discontinued; this limitation may have affected our findings due to the effect of systemic drugs on the vessels. Beta blockers reduce the heart rate ${ }^{44}$ and systemic beta blockers may exert a more significant effect on SRVP compared to topical beta blockers. As SRVP is related to the phase of the cardiac cycle, a reduction in the heart rate may directly decrease the SRVP rate.

In the present study, the control subjects were not age-matched to glaucoma patients. Ageing causes structural changes in the vessels which subsequently affect function. ${ }^{45}$ The incidence of glaucoma increases with age. Thus, our primary glaucoma patients were older than the control subjects. The incidence of SRVP was higher in the older age group. ${ }^{46}$ In this study, age may play a role in the incidence of SRVP in primary glaucoma patients.

A confocal scanning laser ophthalmoscope was used in this study, but "eye movement correction tools" for image movement adjustment were not included. The absence of this special software programme may have affected the accuracy of SRVP detection, in line with a false low incidence of SRVP reported elsewhere. ${ }^{32}$ Therefore, the incidence of SRVP in our study may have been potentially under-reported.

To the best of our knowledge, this is the first study to report the incidence of SRVP in PACG patients. However, the number of PACG patients was too small for any further comparative analysis. There was an even smaller number of patients for analysis according to severity of primary glaucoma, especially moderate glaucoma. This may not provide the actual representation of the association of SRVP and severity. In the future, a larger sample size and prospective cohort study design may provide a clearer understanding of the relationship between SRVP and glaucoma severity.

In conclusion, SRVP is a potential predictive factor for detecting primary glaucoma. The role of SRVP in glaucoma severity remains unclear. A thinner RNFL is associated with lower SRVP incidence. The role of SRVP in PACG patients warrants further studies in the future.

\section{References}

1. Coccius EA. The use of the ophthalmoscope and the indication of a new instrument. Leipzig: Immanuel Muller Publisher; 1853.

2. Jacks AS, Miller NR. Spontaneous retinal venous pulsation: aetiology and significance. J Neurol Neurosurg Psychiatry. 2003;74(1):7.

3. Morgan WH, Hazelton ML, Yu DY. Retinal venous pulsation: Expanding our understanding and use of this enigmatic phenomenon. Prog Retin Eye Res. 2016;55:82-107. 
4. Legler U, Jonas JB. Assessment of the spontaneous pulsations of the central retinal vein in daily ophthalmic practice. Clin Exp Ophthalmol. 2007;35(9):870-871.

5. Abegao Pinto L, Vandewalle E, De Clerck E, Marques-Neves C, Stalmans I. Lack of spontaneous venous pulsation: possible risk indicator in normal tension glaucoma? Acta Ophthalmol. 2013;91(6):514-520.

6. Levin BE. The clinical significance of spontaneous pulsations of the retinal vein. Arch Neurol. 1978;35(1):37-40.

7. Harder B, Jonas JB. Frequency of spontaneous pulsations of the central retinal vein. Br J Ophthalmol. 2007;91(3):401.

8. Morgan WH, Hazelton ML, Azar SL, et al. Retinal venous pulsation in glaucoma and glaucoma suspects. Ophthalmology. 2004;111(8):1489-1494.

9. Pillunat KR, Ventzke S, Spoerl E, Furashova O, Stodtmeister R, Pillunat LE. Central retinal venous pulsation pressure in different stages of primary open-angle glaucoma. $\mathrm{Br} \mathrm{J}$ Ophthalmol. 2014;98(10):1374-1378.

10. Legler U, Jonas JB. Frequency of spontaneous pulsations of the central retinal vein in glaucoma. J Glaucoma. 2009;18(3):210-212.

11. Walsh TJ, Garden JW, Gallagher B. Obliteration of retinal venous pulsations. Am J Ophthalmol. 1969;67(6):954-6.

12. Leske MC, Connell AM, Wu S-Y, et al. Incidence of open-angle glaucoma: the Barbados Eye Studies. Arch Ophthalmol. 2001;119(1):89-95.

13. Gordon MO, Beiser JA, Brandt JD, et al. The Ocular Hypertension Treatment Study: Baseline factors that predict the onset of primary open-angle glaucoma. Arch Ophthalmol. 2002;120(6):714-720.

14. Leske MC, Heijl A, Hussein M, Bengtsson B, Hyman L, Komaroff E. Factors for glaucoma progression and the effect of treatment: The Early Manifest Glaucoma Trial. Arch Ophthalmol. 2003;121(1):48-56.

15. Nouri-Mahdavi K, Hoffman D, Coleman AL, et al. Predictive factors for glaucomatous visual field progression in the Advanced Glaucoma Intervention Study. Ophthalmology. 2004;111(9):1627-1635.

16. Orzalesi N, Rossetti L, Omboni S, Group OS, Conproso. Vascular risk factors in glaucoma: the results of a national survey. Graefes Arch Clin Exp Ophthalmol. 2007;245(6):795-802.

17. European Glaucoma Prevention Study G, Miglior S, Pfeiffer N, et al. Predictive factors for open-angle glaucoma among patients with ocular hypertension in the European Glaucoma Prevention Study. Ophthalmology. 2007;114(1):3-9.

18. Senthil S, Garudadri C, Khanna RC, Sannapaneni K. Angle closure in the Andhra Pradesh Eye Disease Study. Ophthalmology. 2010;117(9):1729-1735.

19. Mitchell P, Smith W, Attebo K, Healey PR. Prevalence of open-angle glaucoma in Australia. The Blue Mountains Eye Study. Ophthalmology. 1996;103(10):1661-1669.

20. Leske MC, Connell AMS, Wu S-Y, Hyman LG, Schachat AP. Risk Factors for open-angle glaucoma: The Barbados Eye Study. Arch Ophthalmol. 1995;113(7):918-924.

21. Yu D-Y, Yu PK, Cringle SJ, Kang MH, Su E-N. Functional and morphological characteristics of the retinal and choroidal vasculature. Prog Retin Eye Res. 2014;40:53-93.

22. Roberts MD, Grau V, Grimm J, et al. Remodeling of the Connective Tissue Microarchitecture of the Lamina Cribrosa in Early Experimental Glaucoma. Invest Ophthalmol Vis Sci. 2009;50(2):681-690.

23. Berdahl JP, Allingham RR, Johnson DH. Cerebrospinal fluid pressure is decreased in primary open-angle glaucoma. Ophthalmology. 2008;115(5):763-768. 
24. Ren R, Jonas JB, Tian G, et al. Cerebrospinal fluid pressure in glaucoma: a prospective study. Ophthalmology. 2010;117(2):259-266.

25. Wang N, Xie X, Yang D, Xian J, Li Y, Ren R, et al. Orbital cerebrospinal fluid space in glaucoma: the Beijing Intracranial And Intraocular Pressure (iCOP) study. Ophthalmology. 2012;119(10):2065-2073. e1.

26. Article 160 of the Federal Constitution of Malaysia. Fifteenth Reprint. Kuala Lumpur: National Malaysia Berhad; 2010.

27. Augusto AB, Luca B, Alessandro B, et al. Terminology and Guidelines for Glaucoma. 4th edition. European Union: Publicomm; 2014.

28. Birt CM, Shin DH, Samudrala V, Hughes BA, Kim C, Lee D. Analysis of reliability indices from Humphrey Visual Field Tests in an urban glaucoma population. Ophthalmology. 1997;104(7):1126-1130.

29. Douglas EG, Fred E, Kenneth S, Joseph C, Marshall NC. Advanced Glaucoma Intervention Study: 2. Visual Field Test Scoring and Reliability. Ophthalmology. 1994;101(8):1445-1455.

30. Rochtchina E, Wang JJ, Taylor B, Wong TY, Mitchell P. Ethnic variability in retinal vessel caliber: a potential source of measurement error from ocular pigmentation?-the Sydney Childhood Eye Study. Invest Ophthalmol Vis Sci. 2008;49(4):1362-1366.

31. Wong TY, Islam FA, Klein R, et al. Retinal vascular caliber, cardiovascular risk factors, and inflammation: the multi-ethnic study of atherosclerosis (MESA). Invest Ophthalmol Vis Sci. 2006;47(6):23412350.

32. Seo JH, Kim TW, Weinreb RN, Kim YA, Kim M. Relationship of intraocular pressure and frequency of spontaneous retinal venous pulsation in primary open-angle glaucoma. Ophthalmology. 2012;119(11):2254-2260.

33. Quigley HA. New paradigms in the mechanisms and management of glaucoma. Eye (Lond). 2005;19(12):1241-1248.

34. Prum JB, Lim MC, Mansberger SL, Stein JD, Moroi SE, Gedde SJ, et al. Primary Open-Angle Glaucoma Suspect Preferred Practice Pattern $\left({ }^{\circledR}\right)$ Guidelines. Ophthalmology. 2016;123(1):P112-51.

35. Golzan SM, Morgan WH, Georgevsky D, Graham SL. Correlation of retinal nerve fibre layer thickness and spontaneous retinal venous pulsations in glaucoma and normal controls. PLoS One. 2015;10(6):e0128433.

36. Lee E, Kim T-W, Kim J-A, Kim JA, Kim H. spontaneous retinal venous pulsation in unilateral primary open-angle glaucoma with low intraocular pressure. J Glaucoma. 2017;26(10):896-901.

37. Foster PJ. Glaucoma in China: how big is the problem? Br J Ophthalmol. 2001;85(11):1277-1282.

38. Levine DN. Spontaneous pulsation of the retinal veins. Microvasc Res. 1998;56(3):154-165.

39. Kain S, Morgan WH, Yu DY. New observations concerning the nature of central retinal vein pulsation. Br J Ophthalmol. 2010;94(7):854-7.

40. Davanger M, Ringvold A, Blika S. The probability of having glaucoma at different IOP levels. Acta Ophthalmologica. 1991;69(5):565-568.

41. Sommer A. Intraocular pressure and glaucoma. Am J Ophthalmol. 1989;107(2):186-188.

42. Paul ER, Halifax, Yvonn MB, et al. Canadian Ophthalmological Society evidence-based clinical practice guidelines for the management of glaucoma in the adult eye. Can J Ophthalmol. 2009;44:S7-S54.

43. Singh K, Spaeth G, Zimmerman T, Minckler D. Target pressure--glaucomatologists' holey grail. Ophthalmology. 2000;107(4):629-630. 
44. Ko DT, Hebert PR, Coffey CS, et al. Adverse effects of $\beta$-blocker therapy for patients with heart failure: A quantitative overview of randomized trials. Arch Intern Med. 2004;164(13):1389-1394.

45. Gates PE, Strain WD, Shore AC. Human endothelial function and microvascular ageing. Exp Physiol. 2009;94(3):311-316.

46. Lorentzen SE. Incidence of spontaneous venous pulsation in the retina. Acta Ophthalmologica. 1970;48(4):765-770. 